\title{
ENGULFED BY THE FAMILY: WOMEN IN THE COLOMBIAN DEVELOPMENT STATE BETWEEN 1966 AND 1990
}

\section{ABSTRACT}

THIS ARTICLE ANALYZES THE EVOLUTION OF SOCIAL POLICY IN COLOMBIA IN RELATION WITH MACROECONOMIC DEVELOPMENT POLICIES AND FAMILY SINCE 1966. UNDERSTANDING THAT MANY LEGAL REFORMS HAVE BEEN UNABLE TO REDISTRIBUTE RESOURCES ACROSS GENDER LINES BECAUSE OF THEIR INABILITY TO FOREGROUND ECONOMIC DEVELOPMENT MODELS AND ITS CONSEQUENCES IN MACRO POLICY FRAMEWORK, THE MAIN OBJECTIVE OF THIS ARTICLE IS TO MAKE EXPLICIT THE LIMITATIONS IMPOSED TO WOMEN BY THEM. ACCORDINGLY, DEVELOPMENT PLANS AND OTHER POLICY DOCUMENTS ARE TAKEN SERIOUSLY IN ORDER TO SHOW THROUGH A CLOSE READING OF THEM THAT THEY LIMIT THE POSSIBILITIES OF REFORMS AIMED AT REDISTRIBUTING RESOURCES TOWARDS WOMEN BECAUSE OF THEIR UNDERSTANDING OF THE FAMILY AS A UNIT THAT WOULD FOLLOW THE LUCK OF ITS MALE HEAD AND AS THE ESSENTIAL SITE OF TRADITIONAL, CULTURAL AND BIOLOGICAL REPRODUCTION. THUS, WOMEN, UNDERSTOOD AS THE RESPONSIBLE FOR HUMAN REPRODUCTION, AND NOT AS WORKERS OR CITIZENS, WERE SUBORDINATED TO THE REPRODUCTION OF PATRIARCHAL FAMILIES, STRUCTURALLY AFFECTING WOMEN'S ACCESS TO RESOURCES.

\section{KEYWORDS}

SOCIAL POLICY; DEVELOPMENT POLICIES; LEGAL REFORM; FEMINISM; COLOMBIA.

\author{
Helena Alviar Garcia* \\ SUBJUGADAS PELA FAMILIA: MULHERES NO ESTADO \\ DESENVOLVIMENTISTA COLOMBIANO ENTRE 1966 E 1990
}

\section{RESUMO}

ESTE ARTIGO ANALISA A EVOLUÇÃO DA POLITICA SOCIAL NA COLOMBIA RELACIONADA ÀS POLÍTICAS DE DESENVOLVIMENTO MACROECONÔMICAS E A FAMILLIA DESDE 1966. PARTINDO DO PRESSUPOSTO DE QUE MUITAS REFORMAS LEGAIS NÃO TÊM SIDO CAPAZES DE REDISTRIBUIR RECURSOS ENTRE AS LINHAS DE GENNERO DEVIDO À SUA INCAPACIDADE DE TRAZER PARA O PRIMEIRO PLANO MODELOS DE DESENVOLVIMENTO ECONÔMICO E SUAS CONSEQUÊNCIAS EM UM QUADRO MAIS AMPLO DE POLITICAS MACRO, O PRINCIPAL OBJETIVO DESTE ARTIGO É O DE TORNAR EXPLÍCITAS AS LIMITACCÕES IMPOSTAS ȦS MULHERES por tal estrutura. Por CONSEguinte, Planos DE DESENVOLVIMENTO E OUTROS DOCUMENTOS PERTINENTES REFERENTES A POLITICAS PÚBLICAS SÃO ANALISADOS MINUCIOSAMENTE COM O INTUITO DE DEMONSTRAR QUE OS MESMOS LIMITAM AS POSSIBILIDADES DE REFORMAS DESTINADAS À REDISTRIBUICĀO DE RECURSOS PARA AS MULHERES, EM FUNÇÃO DE SUA COMPREENSÃO DA FAMÍLIA COMO UMA UNIDADE QUE SEGUE A SORTE DO HOMEM "CHEFE DA FAMÍLIA" E COMO O LOCAL ESSENCIAL DA REPRODUÇÃO TRADICIONAL, CULTURAL E BIOLÓGICA. ASSIM, AS MULHERES, ENTENDIDAS COMO AS RESPONSÁVEIS PELA REPRODUÇÃO HUMANA E NÃO COMO TRABALHADORAS OU CIDADÃS, SÃO SUBORDINADAS À REPRODUÇÃO DE FAMÍLIAS PATRIARCAIS, AFETANDO ESTRUTURALMENTE O ACESSO DAS MULHERES AOS RECURSOS.

\section{PALAVRAS-CHAVE}

Política SOCIAL; POLITICAS DE DESENVOLVIMENTO; REFORMA LEGAL; FEMINISMO; COLÔMBIA. 


\section{INTRODUCTION}

Social policy design in Colombia has been characterized by a faith in law that overestimates the transformative power of legal texts and underestimates the weight of the macro policy framework, embodied in economic development models, administrative regulation, adjudication, and the interaction between diverse legal regimes. As I have argued in previous work (ALVIAR, 2012) (ALVIAR, 2011a) (ALVIAR, 2008a), underestimating the effects of these interactions has structurally determined the failure of generations of legal reforms aimed at redistributing resources across gender lines.

In this article, I present a narrative about the evolution of social policy in connection with macroeconomic development policies and family. From my point of view, any description of social policy cannot be understood without considering the relation between social policy and economic development models (ALVIAR, 2013).

In other articles (ALVIAR, 2011b), I have linked the force of redistributive social policies to the objectives of broader economic development policies. I have argued that resources are effectively allocated according to identities created by development agendas. In this sense, access to social services has operated according to dichotomies such as employed-unemployed, worker-care provider.

In addition to the interaction between economic development and social policy, this article proposes unveiling how ideas about the family determine access to social provisions. In Colombia, before the late 1960s, social policy was seen as part of a broader goal, the goal of industrialization. A product of industrialization was full employment and the policy was import substitution industrialization. The family was defined as a unit that would modernize as a result of the industrialization process. The consequence of full employment would be that the family would receive social services through the employment of the male head of household. The strong link between economic and social policy started to disappear during the early 1970s. During this period, social policy and state provision of certain services played a major role in economic development programs.

During the early 1990s, the economic development model shift brought with it a transformation of the concept of social policy, as well as its relation with the family. Welfare programs stopped being seen as state macro policies and more as targeted instruments to help those who were not able to enter the market due to poverty, age, a disability, or as the result of a lack of human capital.

From a feminist perspective, the transformations that have occurred since the early 1970s have been described as a progress narrative in which, through the years, women have benefited, each time even more, from laws and regulations that help them with their care duties in order to enter the market. Many examples support this way of telling the story. During the early 1980s there were several initiatives set in place to develop forms of cooperative association such as childcare homes, communal restaurants, and public laundries in order to reduce the charge of domestic work (ICBF, 1983). 
This article proposes a different way to tell this story. The aim of my article is to analyze different regulatory initiatives, their interaction with ideas about economic development and their impact upon negotiations within the family. I will do this in order to argue that this interaction limits the possibilities of reforms aimed at promoting a better distribution of resources between men and women.

As a matter of fact and according to many academic accounts, from the beginning of the $20^{\text {th }}$ Century up to the late 1960 s, social and economic policies were intimately linked to the general objective of achieving modernization through industrialization. Industrialization and modernization were connected to specific strategies such as migration from rural areas to cities, the mechanization of agricultural production, the elimination of feudal or semi-feudal forms of social and economic interaction, the formalization of labor relations, and land titling (ALVIAR, 2008b).

The prevalent policy was Import Substitution Industrialization (ISI) and, therefore, social policy design was linked to the development agenda. In addition, between the early 1960s and the end of the 1980s decade, industrialization was centered on policies directed to increase savings and on promoting direct foreign investment. These purposes were articulated to increase the demand for goods, increase industrial production and achieve full employment. Nonetheless, full employment required a more active, interventionist state.

The modernization process consolidated the conception of family as a natural and cultural fact prior to any legal act and independent from economic or social regulation. The family was seen as a unit that would directly benefit from social policies through the male breadwinner. Once the process of industrialization started and full employment was reached, family members would benefit. In addition and probably precisely because it was seen as an appendix of its head, the family was also responsible for "the biological reproduction of the species, the economic sustenance of its members, socialization and learning of children, and conservation of cultural patterns of society" (ICBF, 1983, p. 15).

In the following section, through a few examples of social policies, I will demonstrate that ideas about the family were structured around two concepts: the understanding of the family as a unit that would follow the luck of its male head and as the essential site of traditional, cultural and biological reproduction. This analysis of governmental policies will in turn demonstrate the extent to which women were not the recipients of the distribution of resources as workers or citizens but merely seen as responsible for human reproduction.

My main objective, in this article, is not to develop a new theoretical approach on the impact of development policies on women. Rather, I want to produce a historical account of the relationship between social policy, family and women in Colombia between 1966 and 1990. This account is based on distributional analysis, and particularly on the work of Janet Halley (2010), Duncan Kennedy (1993; 2006) and David 
Kennedy $(2006 ; 2013)$. Their work foregrounds the predominant legal theory at different historical moments and its relationship with economic development theories.

In the area of family law, the contribution of Janet Halley to distributional analysis must be mentioned (HALLEY; RITTICH, 2010; HALLEY, 2011a, 2011b). Her work has recently emphasized the way in which family law has a deep distributive impact, particularly taking into account its interaction with other areas of law, such as social security. In addition, my work is close to that of Kerry Rittich (2002, p. 19), because we are both concerned with the project of examining "in a more structured way the connections between dominant economic development strategies, the specific political and institutional choices to which they are connected, and distributive outcomes."

Thus conceived, my goal in this paper is to produce a historical account of gendered distributional outcomes in the Colombian development state in the 1970s and 1980s through a close reading of development plans and other policy documents. My main argument, as stated above, is that the family engulfed women. Understood as care givers, development policies subordinated their well being and full citizenship to the reproduction of patriarchal families.

\section{THE I970s: PREVEnTING THE RISKS OF WOMEN ENTERING THE WORKFORCE}

\section{i. i Carlos Lleras Restrepo (1966-1970): Industrialization Reforms}

I start in the late 1960s because this was the period within which ISI policies were greatly boosted. As a matter of fact, President Carlos Lleras Restrepo, through his government "of national transformation" strengthened state, led economic intervention to promote import substitution industrialization. According to his development plan:

Import substitution has become an economic need for the country in order to diversify production and increase exportations.

$[\ldots]$

Import substitution appears as a choice that, at the same time, allows decreasing the need for foreign currency and helps sustain the levels of internal activity by means of the production of goods that were imported before.

[...]

The substitution process has given, during the last decade, important results for the economic development of the country and has been particularly intense in the industrial sector. (DNP, 1950, 13-14) 
In terms of the family, this period is important because a state institution in charge of centralizing social provisions for the family was created, the Colombian Institute for Family Wellbeing (Instituto Colombiano de Bienestar Familiar - ICBF for its acronym in Spanish). According to the government, designing an institution dedicated only to family issues opened the possibility to solve problems faced by families in a holistic way. Nevertheless, even before it started to operate in 1969, Lleras stated:

It seems fundamental to delimit the perspectives of action of the ICBF within the context of national development because we have the impression that some sectors of public opinion tend to have higher hopes than it is reasonable to deliver (UNICEF; MINSALUD; DNP, 1970).

\section{i.2 Misael Pastrana Borrero (I970-I974). Demographic explosion and} PROMOTION OF INDUSTRIES

The Development Plan entitled "The four strategies", proposed by this Conservative President, defined social policy "as every action tending to redistribute and increase capital and income, and modifying the structure of the political power by means of profound changes that ensure the access of all groups of the population to State institutions, with the purpose of satisfying the welfare aspirations" (DNP, 1970b, p. 45).

Because it was a conservative, corporatist government, social policy appears clearly linked to communities, peasant organizations and unions. The Plan intended to integrate these social movements' objectives to social policy. In general, its goals were: income redistribution, employment generation, popular groups' participation in politics, and the provision of public services to these groups (DNP, 1970b, p. 53).

The government's first strategy was the promotion of urban development through the private sector by encouraging private savings and housing credits (Decree 677/1972) (Decree 678/1972); however, these offers were directed prevalently to men. The Government's policy specifically moved away from industrialization and understood the construction sector's importance to generate employment and respond to Colombians' migration from the countryside to the cities (ELTIEMPO, 1997). According to the Development Plan:

Our purpose is to contribute to a large and dynamic construction industry, in great measure self-financed, that produces better wages for hundreds of workers, and that adds new units of urban housing and related services.

(DNP, 1970a, p. 6)

Furthermore, along with increasing housing supply, this strategy aimed for an expansion of labor demand within the construction sector and a boost in consumption. ${ }^{1}$ 
In addition, this strategy understood economic growth as intimately linked to redistribution in order to achieve greater equality and general welfare. In this sense, the plan redefines development "as the achievement of a sufficient degree of material abundance and a sufficient degree of distribution of such abundance” (DNP, 1970a, p. 22).

Within the framework of the Development Plan, it is understood that "The family should be the basic unit and specific object of economic and social development, and should aspire to fulfill itself in the best conditions of material and spiritual wellbeing" (DNP, 1970b, p. 41). This scheme led the government to set as criteria in order to evaluate the success the improvement of low-income families' quality of life.

Additionally, the Pastrana government emphasized a full employment policy. In 1970, the ILO prepared the report "Towards full employment: A programme for Colombia" that would impact the design of social policy. As a consequence, in 1970 a National Committee was established in order to assess the ILO report. For this Committee:

Only by means of the redistribution of income, in the country, it will be possible to simultaneously achieve a rapid rate of growth in employment and production because social change is a prerequisite for economic development. A statement that overcomes, fortunately and without ambiguousness, the Byzantine controversy over which the economic or social development should be a priority [...] From this perspective, economic development cannot be divorced from social development. (MINTRABAJO, 1971 , p. 6)

As it was typical during this period in economic development theories (ALVIAR, 2008a), the Pastrana government had a special concern for population growth. According to the sectorial program on population included in The Development Plan, the Colombian family was expanding: "the demographic reality in Colombia is very similar to that presented in many developing countries: rapid population growth, high fertility rates, rapid decline in mortality [...]" (DNP, 1970b, p. 34). The strategy proposed increasing education standards to impact the fertility rates both at a society and family levels and achieve smaller families.

Consequently, the government strongly promoted family planning programs. In his speech to Congress in 1973, Pastrana insisted that the government's efforts to meet the needs of Colombians would be diluted if there was an uncontrolled population growth. Due to this condition, the government proposed a policy which had the following goals: 1) redistributing the population in order to have a better distribution, 2) reducing the mortality rates, and 3) altering the trend of population growth (PASTRANA, 1973).

In a similar sense, the Committee's document that evaluated the ILO report indicates: 
Full employment, and overall development that comprises the progressive rising of the living standards of all people, it is not possible without a population policy that encourages responsibility of parents facing the future of their children and society and it begins with proper sexual education and family planning. (MINTRABAJO, 1971, p. 33)

Additionally, during this period, pensions for widows and orphans were extended, family subsidies were provided, community centers for children and the national nutrition plan began, and the family doctor system started.

In 1972, the Community Centers for Children (CCI in Spanish) were created to provide children's early education. Two years later, Preschool Care Centers (CAIP in Spanish) were created to promote the development of children under five years who lived in vulnerable families (ICBF, n.d.). The President justified the Community Centers for children as a way to protect them from the fact that women were being forced to work outside of their house:

[A]bout $60 \%$ of the Colombian population has low income, unemployment, lack of adequate housing, these factors greatly affect children, who are so subject to conditions of social and economic deprivation.

[...]

The slum, forces the mother to leave her children in an inhuman solitude, without a minimum physical, mental or social protection while she seeks a livelihood through work.

$[\ldots]$

This program is therefore a new concept of integrated prevention and promotion of family, which touches roots of the family: mother and younger children. (PASTRANA, 1973)

Community Centers for children were put into operation providing support for communities in cash and in kind. The Centers were intended to protect minors but also to reduce problems such as malnutrition, the dissolution of the family unit and certain community conflicts.

The presence of the ICBF translates into a series of protective actions with a healing concept, and resorts to the fields of rehabilitation, psychosocial adaptation, recreation and training. But first the Institute compromises its scientific capacity to prevent family dissolution (PASTRANA, 1973, p. 170). 
I.3 Alfonso Lopez Michelsen (1974-I978). The Crisis of the modernization model Alfonso Lopez Michelsen's period of government signals the initial stages of the critique of certain ISI policies. Specifically, the government was very critical of the set of policies that were aimed at promoting migration from rural areas to cities.

Socially the effects are still felt. The breakdown of social expectations generated by the modernization process, to which we have referred, are expressed in a growing process of rural and urban marginality, excessive growth of the informal sector and worsening of the social phenomena of crime and corruption.

It is no longer about trying to sort out the modernization drive in an essentially rural economy: the complexity acquired by the Colombian economy and society demanded intervention mechanisms from the State to deal with this complexity. (DNP, 1974a, p. 2)

The critique was intimately related to the fact that the promise of modernization had not reached most of the Colombian population. The President explained his frustration:

Since the 1930s, when our country has had the same development plan that consisted in a strong support and the protection to the modern sector of the economy [...] In the past, this development goal was probably needed. The industrialization and modernization of our economy had to begin, nevertheless little did this kind of development benefit the mass of landless laborers and smallholders [...] The development plan now presented to Congress seeks to close the gaps that the traditional development model has created [...] The program we offer the country is to change policy goals, and try to protect traditional sectors in rural and urban areas and target public investment primarily in public works in intermediate and small cities, and also in rural areas where the poor are concentrated. (DNP, 1974a, p. 2)

The Development Plan changes the economic model from one that emphasized modernization and industrial protection to a model geared toward generating greater equality and social investment.

In words of Lopez:

I think the great task of this government, from an intellectual and political perspective, is to have questioned the dogma that a country is great insofar as it is industrialized. No, it is great only to the extent that all sectors grow 
together and a country cannot be industrialized if it does not have the capacity to produce raw material and the ability to produce food in the same measure that raises the living standard of workers linked to the industry. This government has spoken of a development model different from the one that had been imposed on the country over the past 40 years, overprotecting industry. The fundamental differences between the two models are:

a) Greater emphasis in the current model to promote a balanced or parallel growth... as opposed to the strategy of growth based in the concentration of stimuli in a leading sector (e.g. industry or construction) which should theoretically create a spillover effect on the entire economy.

b) Greater emphasis on export promotion, which means an increase in the efficiency of domestic production as a condition sine qua non, in contrast to the policy of promoting import substitution behind a Chinese wall of tariffs.

Historically the Colombian growth strategy, supported by import substitution, came forward with preferential support from the manufacturing industry, generating unbalanced growth, relative to other sectors, but especially to agriculture. (LOPEZ, 1978)

One of the worst effects that the traditional model of import substitution generated was an unequal distribution of resources for families of different social classes. $^{2}$ For the families of those who had formal jobs, there were many benefits that came with this fact.

In addition, families were changing. A document prepared by ECLAC for Colombia describes this trend in the following way:

Two events had enormous impact on the Colombian family between 1950 and 1970: the expansion of the school system and the entry of women to education and labor force, changed social expectations in all groups and heavily modified the behaviors in fertility, which resulted in a decrease in the birth rate and a profound change in marriage patterns. (PARRA, 1987, p. 22)

Indeed, in 1968 and 1969, the total marital fertility rate was 9 children and it dropped to 6.5 children by 1980 (ICBF, 1983, p. 35).

Despite the change in the industrialization model, the Lopez government kept the full employment policy. In this sense, the macroeconomic policies regarding agricultural, industrial, exportation, regional and urban development programs were designed to achieve the same goals of full employment and equality. The difference 
was that the government promoted the provision of social services and emphasized rural development, as it understood that investing in the agricultural sector rather than in the manufacturing or construction would generate more employment. Therefore, government spending was geared toward an increase in rural quality of life. ${ }^{3}$

In social terms, this government proposed The National Food and Nutrition Plan (Plan Nacional de Alimentación y Nutrición — PAN — in Spanish) that sought to generate an adequate diet for children, mothers and educate families on distribution and food preparation. In addition, attacking malnutrition was seen as a way to improve physical and mental conditions of the workforce in order to improve productivity.

Along with PAN, this government created the Integration Services Program in Marginal Areas (Programa de Integración de Servicios en Zonas Marginadas) was promoted. It had among its objectives:

- Protect families 'through preferential attention to children and youth through preschool services for children 0-7 years old, school services for the population of ages 7-14 and a state action in the fields of culture, health, nutrition, recreation and sport.

- Increase family income through job creation, training and the promotion of individual or communal companies.

- Facilitating housing credit for slum dwellers.

- Create local development centers to provide services for families and work banks. (DNP, 1974c, p. 33)

Finally, Law 27 of 1974 created the Centers of Preschool Care (Centros de Atención Integral al Preescolar-CAIP). The main task of these centers was to educate families on issues related to nutrition, childcare, health care and developmental psychology.

Interestingly, the Lopez Michelsen's development plan established a trend that can be linked to conditional cash transfers of the 1990s as it states that women could work part time in this centers: "it is desirable to further establish the possibility of part-time jobs in these centers to facilitate housewives and students of both sexes who have adequate preparation, and who can engage in this kind of work.” (SIP, 1975, p. 33).

Family changes, and even some of the most serious social problems are attributed largely to the reduced presence of women at home:

The biggest changes within the urban family have been produced by the massive access of women to education and work, which has also pushed changes in socialization and has generated at the same time new needs (daycare, preschool care), and new pressures on the family structure (drug addiction, crime, unemployment). (DNP, 1974c, p. 23) 
Even though Lopez and his government members were considered progressive liberals, public documents seem to move between a very traditional understanding of the role of the family along with greater equality for women. As a matter of fact, he passed Decree 2820 of 1974, which modified a few Civil Code articles and was aimed at granting equal rights and obligations for women and men. The reform was summarized by the government in the following terms:

Children are to obey the mother as the father [...], the mother may also correct and punish children. The new legislation takes into account that the mother is the one who is closer to his children. It extends to the mother the power to monitor their behavior, correct and punish them moderately. [...]

The mother also legally represents her children [...] the husband is not the only one that manages home. The wife must share the leadership of the family. The wife and husband have the same rights and the same duties directing the household. Gone is the "marital power" that required a wife to blindly obey the husband. Consequently, they both have the same authority and should direct the family together.

$[\ldots]$

Neither the husband nor the wife gives more orders than the other. The two have to help each other. The former "macho" Civil Code forced woman to keep obedience to the man in exchange for protection that she would supposedly receive from him.

[...]

Also women should contribute to the household if she finds the way to do it. Previously, the law stated that the husband was the main provider and only in the event that he had nothing to contribute, the woman would do it. Now, women enjoy equality in relation to man and should to contribute in the event of having property or income.

[...]

The existing discrimination against married women is eliminated: the law considered her "incompetent" [...] this is explained on the grounds that a married woman was under the authority of her husband.

[...]

The husband no longer manages his wife's assets, they create a society together. (PRESIDENCIA, 1975, p. 57)

In addition, the Lopez government launched the creation of courts specialized in family matters. 


\section{I.4 Julio Cesar Turbay (1978-1982). Changes in the family and strengthens} INCENTIVES FOR DOMESTIC INDUSTRY ONCE AGAIN

The Turbay government went back to Import Substitution Industrialization full force. The labor results of this policy, according to government reports, include an increase in the economically active population (EAP) from $49.9 \%$ in 1978 to $51.8 \%$ in 1981. The report also presents the following facts and figures:

This growth in labor supply notoriously pushed for the creation of new jobs, such a way that only between 1979 and 1980, a number of 451 thousand jobs were created.

The most dynamic economic sectors and those with greater employment percent growth have been mining, electricity, gas and water, construction, trade and finance. Nonetheless, trade, manufacture industry, services, and construction are the ones with the greatest volume of job creation.

Nearly $55 \%$ if those new jobs corresponded to employees and workers, $43 \%$ to self employed, $1.5 \%$ to family employees and 0.9 to employers. (TURBAY, 1982, p. 18)

This government's Development Plan highlights the growth of public social spending in the 1970s and emphasizes that the national budget increased from $31.3 \%$ in 1970, to 40.9\% in 1978 (DNP, 1978a, p. 10). Nevertheless, according to the Plan, even though Colombians had higher incomes and better jobs social problems persisted. Within the problems in Turbay's Development plan family related problems, such as high infant mortality, school dropouts, and lack of protection for early childhood, standout (DNP, 1978b, p. 85). ${ }^{4}$

As in the previous government, family changes that took place during the Turbay government, particularly the fact that women worked and spent less time at home, produced social problems that required new policies. According to Turbay's National Integration Plan:

$[T]$ he increase in the participation of women in the labor force, shifts from the extended family to the nuclear family and the slow growth of infrastructure to serve the preschooler have led to an increase in the vulnerability of children during their first years. (DNP, 1978b, p. 85) $[\ldots]$

The process of socialization and children care, traditionally performed by women within the family, has been affected by the growing female participation in the labor force and the shift from patterns of extended to nuclear family as well as the effects of urban settings upon family life. The space left by these transformations requires that society and the State 
design new and appropriate instruments for the attention to this age group. (DNP, 1978b, p. 95)

This interpretation is reiterated in the following quotes from the document evaluating the end of his term:

The rapid urbanization of the country and the demographic transition experienced in the last decade have created new problems that are affecting the stability of social structure and family organization, such as the irresponsibility of the procreation of children, the abandonment of the child and malnutrition, among others.

[...]

Considering these problems led the national government to design the new social policy-in, which children attention was highlighted as a priority that would address comprehensively the situation. (TURBAY, 1982, p. 201).

One of the most striking characteristics of these quotes is the complete disengagement from women's issues or problems as individuals. Their main role is as mothers and children are at the center of the public policies concerns.

The solution, obviously, was the creation of a system that would improve the lives of children within the family; as a consequence, Law 7 of 1979 was passed. This law reorganizes the ICBF and creates the National Family Welfare System (Sistema Nacional de Bienestar Familiar) whose purpose is to "promote harmonious integration and realization of the family, to protect children and guarantee their rights, and coordinate relevant government entities to handle the problems of the family and the child, with the purpose of raising the standard of living of society." (TURBAY, 1982, p. 201).

For this government, the Centers for Preschool Care (Centros de Atención Integral al Preescolar-CAIPS) created in the Lopez Michelsen government, supplied somehow, maternal care and they have a real family function instruction:

Through its eight years of operation, the children's homes or preschool care center have adopted the needs of the Colombian people, to become the center from which education and orientation are given to parents in the process of socialization and integrated development of their children and instruction on family life is given.

Children's homes replace in varying degrees maternal care through activities aimed at creating the necessary conditions for the successful development and growth of preschool children, children of working 
mothers, unemployed parents, or orphan children. (TURBAY, 1982, p. 202)

In 1978, there were 760 children's homes and they increased to 1,434 in 1982 reaching 150,000 slots to meet the needs of children under 7 . In 1981, men headed 79\% of households and the average number of children of the Colombian family (urban and rural) was 5.4 (DANE; DNP, 1981). Furthermore, couples formed 67.5\% of the families that benefited from the CAIP program in 1977. Additionally, beneficiary families of this program at the time were mainly low and mid-low socioeconomic classes and women who faced poor labor conditions (BONILLA, 1982, p. 69-84). ${ }^{5}$

\section{I980S: THE INITIAL STAGES OF THE SHIFT IN THE DESIGN OF FAMILY ORIENTED POLICIES}

2. I Belisario Betancur (i982-i986). The year of the family under a CONSERVATIVe GOVERNMENT: OPENING THE BLACK BOX?

Through Resolution 553/1981 the General Assembly of the Organization of American States declared 1983 as the Inter-American Family Year. Accordingly, the government supported this celebration and declared the Year of the Colombian Family. As a consequence, a steering committee and regional councils were established in order to promote the modernization of family law, encourage research on its characterization, education and specific policy design (DNP, 1982a).

One of the main objectives of declaring a Family Year was to emphasize the positive aspects of family to reinforce its meaning as the "essence of life":

A process of awareness and reflection on the importance of the family as the basic unit of production and social reproduction was encouraged and strengthened in various sectors of the country. (ICBF, 1983, p. 9)

In the opening speech of the Family Year, President Betancur held that despite social transformations, young people should continue understanding the importance of family life:

Yesterday, when I meditated on the situation of family in Colombia, I learned a really exciting fact: in the city area of Bogota there are more than 3,500 applications of couples who want to participate in marriage encounters and patiently await their turn. I was informed that the same happens in various cities; and the number of marriages that seek guidance in order to restore marriage, grow every day. 
I clearly understand that we suffer the impact of negative news every day $[. .$.$] the same happens within a household. One sometimes has the$ impression that the Colombian family is falling apart; that it has ceased to be the center of affection, of selflessness, of hope. But we ought to know that against the attacks of a growing social dissipation, thousands of young couples want to strengthen their union and the future spouses want to have a clear awareness of what it means for them and for society their commitment and mutual surrender. (BETANCUR, 1983)

This government not only takes the family as the moral unit of society but also as the one that provides the workforce and drives economic development:

The family complies with responsibilities that are essential to economic and social development, including: the renewal and growth of the population, satisfying the basic needs of workers, the socialization of children. (ICBF, 1983 , p. 28)

The Family Year encouraged extensive discussions that, somehow, opened the black box of the family to explore its internal structure. Government studies of the time draw attention to the roles of men and women at home:

The "macho" cultural value still prevails within the Colombian family as it has permeated the family organization. There is a sexual division of labor by which men are the supreme authority and play a fundamental economic role, while women perform household chores and the socialization of children, being the female figure closest to the children while the father is an absent, aggressive and authoritarian image. (ICBF, 1983, p. 32)

The reason why the family should be the goal of social policy design is because it plays a fundamental role in society: the growth and renewal of population:

Family units are crucial for the development of society due to the fact that it is inside family where renewal and population growth is ensured. Within family the biological and psychosocial ability of individuals develop, values, norms and patterns of social behavior are transmitted and productive functions of our society take place. It has been considered appropriate that the State and society define the family as the fundamental objective of social policy, from the formulation of activities to assist the family unit holistically and within a framework of inter-institutional coordination. (ICBF, 1983, p. 58) 
In an interesting turn, the document includes the burden of domestic work upon women:

Domestic work is the set of activities that take place within family in order to replenish the labor capacity of individuals and socialization of new generations, and despite being indispensable to economic and social development, it is not recognized as such.

In Colombia this work has been traditionally assigned to women who have accepted it as a "natural" condition of their sex, while the main task of men is linked to productive activities and earning the income required for family subsistence. This sexual division of labor is common among Colombian households because most married women report being housewives and do not participate in labor force.

Although this cultural practice is prevalent in all social classes, domestic work is particularly arduous and difficult in the lower stratum due to lack of sufficient income to acquire the tools necessary to perform their jobs, lack of adequate housing, water, energy and overall utilities.

Women in this stratum are the most inhibited to participate in occupationally modern-type activities, political, cultural and social life of the country.

Because of the lack recognition of domestic work, the State has not thought of a policy to facilitate the fulfillment of these tasks, both for women and families. (ICBF, 1983, p. 36)

In a similar way, the Development Plan states that "[s]pecial attention will be paid to the social advancement of women, moving along in the processes of integration into productive life, improving conditions of domestic work and promoting the participation of women in the productive, cultural and political life of the country on a basis of equal rights" (DNP, 1982a, p. 37). However, it must be remembered that Betancur's government was a conservative one, and even though his Development Plan stated that objective, it was a rather marginal goal. This can even be seen within the structure of the Plan, taking into account that the above quoted sentence is the last one in a heading dedicated to the family. In this sense, even though it seems to be progressive for women's situation, it is a marginal annotation within the Development Plan, and the fact that women are included within a heading considering family indicates that a traditional image of women is maintained.

During Family Year, several objectives and strategies are aimed at women:

Encourage the participation of women in productive life in the same conditions as those of men, as well as in political and cultural activities. 
Enable the development of tasks related to domestic work and socialization of children. (ICBF, 1983, p. 61)

To meet these objectives, some strategies are presented:

- Promoting cooperative forms to make the realization of domestic work easier, as laundries, community kitchens and tenements.

- Educating the family about the need to perform collectively the domestic work.

- Including within life education programs contents addressed to show the equality in relations between the sexes, responsible paternity and some other appraising aspects. (ICBF, 1983, p. 61)

Betancur refers to the transformations within the family in the following terms:

These last decades the social life conditions have varied greatly. It is impossible today to think exclusively about those patriarchal families who met every day around a prodigal table to talk, under the authority of the male, about the multiple aspects of his everyday worries. Today, the authority is shared; the woman is neither relegated to a secondary role nor dependent; and the children are not as quiet and obedient as before.

[...]

I can tell that about this matter, I am also optimist, and I want to transmit this optimism to my fellow countrymen. I can see a clear revival of love as a fruitful base of unity and familiar stability. It is not anymore the force of law in the social criticism what keeps a family united and strong in its vocation, but that warm and profound love that supposes the understanding, delicacy and capacity to confront jointly the thousand faces of existence.

(BETANCUR, 1983)

As the former governments, the Betancur government shows that greater women's labor participation is one of the causes of serious social problems:

The greater participation of women in the workforce has had enormous repercussions in familiar organization and in women's life. In ten years $(1970-1980)$, the economically active female population increased from $31 \%$ to $39 \%$. Working does not exonerate women from domestic work, so we calculate that women fulfill workdays of 16 hours if we consider both tasks. (ICBF, 1983, p. 56) 
Regarding the situation of rural family, Betancur considers that:

In 1978 , it is possible to observe a tendency toward female participation in modern categories, specially a considerable portion of women in the agribusiness sector, possibly in transformation and conservation of food. Specific regional studies have allowed us to observe that this female activity influences the semi abandonment of children in a similar way that in urban sectors. There are not any preschool protection programs since the attention covering is even lower than that of the city. (ICBF, 1983, p. 41)

In that respect, it has to be noted how this government considers that "incomplete" homes are more inclined to produce social problems.

The transformations of the Colombian society such as the intense urbanization process, greater participation of women in the labor market and peasant migration have modified the ancient forms of family organization. In the marginal classes of cities, delinquency, abandonment of minors, and families conformed only by mother and children join unemployment and poorness. (DNP, 1982b, p. 36)

The government shows that among poor families incomplete homes are more common: $20.8 \%$ have women as heads of households. Incomplete homes, generally without a paternal figure, "are linked to several problems for minors, such as abandonment and other social pathologies" (ICBF, 1983, p. 33).

As the following paragraphs will show and notwithstanding the insight about the difficulties women face because of the so called double shift, the government continues to center its policy design around children and women as mothers.

In the inaugural speech of the family year, Betancur says that the family attention programs have forgotten about the transformations carried out over this institution, a situation that has damaged the efficacy of those programs.

I wish to emphasize another aspect that shows that singularly positive tendency of strengthening the family in Colombia: family community work is being tried, together with the individual work that isolated the familiar core and even came to be opposed to it.

$[\ldots]$

These programs of integral attention to households are the ones we want to stimulate and promote in this Inter-American family year, a good choice by the OAS and by the Inter-American Women Commission to magnify 
the familiar unity as a decisive factor in the march of our communities toward progress.

But beside this consoling reality, there is another less joyful reality: the absence of an integral organization between the processes of development and the transformations of the family and the real incoordination between public and private organizations diminish the efficacy of the programs oriented toward family welfare. (BETANCUR, 1983)

The National Development Plan establishes as a priority the integral attention of the family. In general terms, the Plan is based on the principles of stability, growing and equity. This document recognizes the effects of the world crisis over national economy and proposes shock measures and measures of longer range: "The state task expressed in Government policies prompts the production and promotes the leveling of opportunities of progress for individuals and families within a framework of liberty and social justice" (DNP, 1982b, p. 58).

The policy of integral attention to the family "constitutes a set of actions integrated and coordinated in the fields of employment, healthcare, nutrition, education, recreation, and community participation, in order to join the national development with the increase of the family wellbeing" (DNP, 1982b, p. 58). This policy shows the importance of employment, income and social security. Two concerns are frequent in the Plan: labor informality and the increment of infant work: "Families hardly compensate the individual low incomes with the work of children, women and old people, to obtain incomes that amount to the value of the family expenses. It is also typical in families the combination of members working in both sectors of the economy, the modern and the informal ones" (DNP, 1982b, p. 58).

The Development Plan assumes that formalization of employment is fundamental for family comfort: "The general objective of the social security policy will be to offer integral attention to the worker and his family, increasing the coverage and improving the quality of the medical and recreation services" (DNP, 1982a, p. 9, emphasis added).

This intention supposes that when social security for the home provider is guaranteed, the other members of the household, including the wife, will benefit. The government policy included massive housing construction, employment generation, and the reorientation of family expenses toward a better diet to constitute the "solid base" for families and communities (DNP, 1982b, p. 42). At the end of his government, 400 thousand houses had been built (REVISTA SEMANA, 1983, 1986).

Betancur's government received recommendations from the IMF, which included:

Public spending cuts, salary raises below inflation, monetary devaluation, subsidy elimination and increases in public utility services fees. One of 
the consequences of adjustment policies was the reduction of public social spending. Between 1983 and 1985 health investment budget was reduced significantly, limiting the expansion of the sector and even hindering the maintenance of certain public services in their previous level.

(FRESNEDA et al., 2009, p. 19)

This policies promoted by Betancur's government following the IMF recommendations of 1984 were implemented in the context of a series of efforts in which Betancur was engaged in order to reach a Latin-American response to the debt crisis, which he promoted in the UN Conference for Commerce and Development (Unctad), in the Economic Commission for Latin American and the Caribbean (ECLAC), and in the Organization of American States. However, after the failure to reach a joint response on behalf of debtor countries, Betancur decided to follow the IMF recommendations (GONCALVES; SOTO, 1992, p. 11-22). This actually led to an accelerated decrease of the fiscal deficit, accompanied with the reduction of the social spending. Also, the minimum wage increased its spending ability until 1986, but this ability diminished from 1986 to 1989 (FRESNEDA et al., 2009, p. 19).

\subsection{Virgilio Barco (I986-I990): COMPeTING VIEWS OF Gender}

By the end of the 1980s, Colombia was still struggling between growing poverty and inequality, and the exacerbation of the war with drug cartels. In this context, Barco proposed to change the development model. The government pointed out:

With import substitution, Colombia definitely enters a process of diversification of its production structure. Until the second postwar period, this structure was characterized by a marked tendency toward specialization in the production of primary exporting goods, mainly coffee. In the late 50s, an important industrial sector began to consolidate and agricultural production grew rapidly, particularly the commercial crops. In the following years a gradual opening of the economy to the world market occurs, which aided the transition from being a single exporter to searching for a greater diversification of its exports.

In particular, the industrialization process allowed the consolidation of the major urban centers of the country (Bogota, Medellin, Cali and Barranquilla), making them and their areas of influence important population receptors. (PRESIDENCIA DE LA REPÚBLICA; CRNR; SIN, 1986, p. 48)

The model that Barco called "Social Economy" focused on regional imbalances as a consequence of the development model traditionally set forth in Colombia, which had excluded certain regions: 
In fact, the persistence of inequalities in the development of regions somehow explains the disparities in personal and family income distribution. [...] This territorial dimension of social inequalities whereby purely geographical factors affect inequality in income distribution has not been properly assessed either in analysis or policy design. (PRESIDENCIA DE LA REPÚBLICA; CRNR; SIN, 1986, p. 9)

During this period, $45 \%$ of the population lived in poverty, and in rural areas this percentage reached $60 \%$. In addition, $76 \%$ of Colombians living in municipalities with less than one hundred thousand people did not have their basic needs satisfied (PRESIDENCIA DE LA REPÚBLICA; CRNR; SIN, 1986, p. 6).

Barco's model of Social Economy aimed at achieving a balance between production growth and equitable distribution of income. According to his proposal to achieve this balance, "it is necessary to modify both the economic growth composition and the content of distributive policies, in such a way that these become more than compensation formulas and transform into effective instruments to support growth" (PRESIDENCIA DE LA REPÚBLICA; CRNR; SIN, 1986, p. 1). This development policy shifts from direct redistribution through taxes and public spending to the idea of making the pie bigger for the poor (PRESIDENCIA DE LA REPÚBLICA; CRNR; SIN, p. 4).

This liberal government retakes the discourse of modernization and emphasizes the integration of more citizens into the market.

The Social development strategy aims to ensure the access of everybody to the physical, social and productive assets necessary for their social security, their active involvement in the production and consumption, and their participation in the democratic government of the nation. The sectorial guidelines of this strategy are [...] to modernize the management of the entities responsible for the provision of social services. (DNP, 1986a, p. 20)

It is interesting to note that with this shift, this government opens the door to structural economic reforms to be implemented in the years to come.

State action focuses on the process of income generation, seeking to create opportunities for linking the poor to the activities of production and consumption. This will allow in the medium term to increase the capacity of saving and capital accumulation in these strata of population so that they can contribute to overall economic growth. (PRESIDENCIA DE LA REPÚBLICA; CRNR; SIN, 1986, p. 28) 
As in previous cases, the Development Plan established as a social objective the improvement of household welfare and women play a part mostly as child bearers. Tellingly enough, women appear in the heading devoted to the social policies regarding households. In this regard, Barco's Development Plan establishes that "[t]he households need that the State must directly address are related with the protection of maternity" (DNP, 1986b, p. 50). Accordingly, "[t]he National Government started a program for the improvement of the nutritional state of pregnant women and new born child" (DNP, 1986b, p. 56).

Notwithstanding, this univocal and unchanging understanding of women's role in society, there is a glimpse of the initial stages of an equality discussion. In several documents produced by Barco's government, there are allusions to gender inequality, and the importance of overcoming it. For example, in the context of human rights, Barco's Counselor for the Defense, Protection, and Promotion of Human Rights recognized the persistence of racial and sexual inequality "in labor and family life" (PRESIDENCIA DE LA REPÚBLICA; CRNR; SIN, 1986, p. 6), and thus he promised that the government would engage in studies about women's rights, among others (PRESIDENCIA DE LA REPÚBLICA; CRNR; SIN, 1986, p. 20). Also, after promoting a constitutional reform, Barco stated that "[m]any of the Articles of the reform that I have presented deal with matters oriented toward the promotion and guarantee of social rights, among which are those related to the insurance of equitable and satisfactory conditions of work for both men and women, including equal pay" (BARCO, 1988, p. 42). Following this vision, Barco's Government issued Decree 1398 of 1990, "that eliminates all forms of discrimination against women”, and has a particular emphasis on the situation of women in labor and family life (BARCO, 1990, p. 72).

\section{Conclusions}

As I stated in the introduction, the goal of this paper was to produce a historical account of the gendered distributional outcomes in the Colombian development state in the 1970s and 1980s. After this chronological tour of the different economic development shifts and their corresponding understanding of the family unit as a privileged site for social transformation and the essential unit to preserve traditional values, it is very evident that this interaction structurally affected women's access to both public and private resources.

Because social policies aimed at women only identified them as responsible for child reproduction, they were not seen as recipients-in their own right-of public spending geared towards greater access to jobs, social security or the development of human capabilities. In addition, economic development plans designed job creation policies designed for men: steel and automobile industry and the construction sector. 
In the 1980s and early 1990s, slight glimmers of the discourse of gender equality begin to appear. Nevertheless, a traditional understanding of the family and the adequate role of women within it creates a strong limit upon the goals of equality.

Although the objective of this paper is merely historical, some insights can be extracted from my previous account. As I mentioned in the introduction, following economic development ideas, and resources are allocated according to identities underlying particular development agendas. In the above account, the identity of women as caregivers was particularly important and operated to allocate resources to men and to create incentives for a particular kind of household that benefits men. This fact tends to be marginalized by accounts that understand the family as a natural and cultural fact prior to any legal act and independent from economic regulation.

This paper's objective is to show that the particular distributional outcomes produced by the economic development policies adopted in Colombia in the 1970s and 1980s were not natural, nor neutral. Rather, it emphasizes the fact that they are produced by particular choices in development agendas, and that there are alternative choices that can be made. In this sense, by foregrounding the choices made by economic development documents, which are then "translated" into legal rules, my argument opens up the possibility of starting a dialogue around the ways in which resources can be reallocated in different ways through more conscious and egalitarian choices.

\section{NOTES}

* Full Professor and Dean of Universidad de Los Andes, Bogotá, Colombia. The author wishes to thank Luisa Cano and Emilio Lehoucq for their invaluable research assistance in the production of this article.

1 "It has the advantage of creating new and better jobs in construction, as well as additional jobs in transportation, in the construction materials industry and in general in the rest of the economy through increases in the demand for massive consumption goods." (DNP, 1970a, p. 48)

2 "The existing data allows having a relatively precise vision of the evolution of urban income distribution since mid-1960s. [...] Between that period and 1976, urban income distribution deteriorated. [...] The deterioration tendency of urban income during this period is also consistent with the poverty studies, which indicate that the most critical levels were reached precisely during the mid-1970s." (OCAMPO, BERNAL, AVELLA \& ERRÁZURIZ, 1994, p. 330)

3 "The main public spending government programs] are aimed at giving the poorest population access to basic social services. Therefore, it arises a great effort to improve education, health and safe drinking water services 
in rural areas. These actions, beyond benefiting the poorest families, contribute to a more equilibrated regional development and to an employment policy. It has been considered that, in the long run, the most effective employment policy is providing to provide the workforce good education and health in order to make it employable." (DNP, 1974a, p. 4)

4 But no everything is positive. At least three areas of concern subsist. First, despite all the state and the community's effort severe problems prevail such as the high infant mortality rate, school desertion, low quality education and underemployment. Second, and in good measure as a result of the same growing process, new social problems emerged, as the lack of protection for the early child due to the increasing participation of women in the labor market, the higher incidence rate of accidents in the big cities and the senior attention problems. But probably the most alarming is the fact that the growth dynamics of the country, by not evenly distributing its benefits, hasn't not only failed to fully incorporate in the development process some traditionally margined groups but, additionally, it has leaved behind other sectors of the population.

5 "None of the women users of the CAIP have management positions. Likewise, it is observed that within the dominant group of professionals and technicians, primary teachers and nurses are predominant, and among service workers almost half of them are housemaids by days. About $60 \%$ of the merchants and vendors have 'marginal' labors such as street food sales and even in this group scrap metal from recyclable material they themselves picked from the trash was traded. [...] As a whole the perceived family incomes were really low. The hardest economical conditions are without a doubt those of families in which women are heads of household."

\section{REFERENCES}

ALVIAR GARCíA, H. (2008a). Derecho, desarrollo y feminismo en América Latina. Bogotá: Editorial Temis y Ediciones Uniandes.

(2008b). The Classroom and the Clinic: The Relationship between Clinical Legal Education, Economic Development and Social Transformation. Journal of International Law and Foreign Affairs. 2008. Num. 13. . (2011a). "Legal reform, social policy, and gendered redistribution in Colombia: The role of the family”. American University Journal of Gender, Social Policy \& the Law, 19, p. 577-599.

. (2011b). “The Unending Quest for Land: The Tale of Broken Constitutional Promises”. Texas Law Review. Vol. 89 p. 1895.

. (2012). "Searching for Women and Sustainable Development in Colombia: Restructuring the Limits”. Fordham Environmental Law Review, XXIII (2), p. 22-43.

. (2013). "Social Policy and the New Development State: The Case of Colombia." In: ALVIAR

GARCÍA, H.; TRUBEK, D.; COUTINHO, D.; SANTOS, A. Law and the new developmental State, The Brazilian experience in the Latin American context. Ireland: Cambridge University Press.

BARCO, V. (1988). Proyecto de Reforma Constitucional. Democracia participativa y Justicia Social. Bogotá: Presidencia de la República.

(1990). La Economía Social: Estabilidad, progreso y modernización. Informe del Presidente de la República al Congreso Nacional. Tomo X. Bogotá: Presidencia de la República.

BETANCUR, B. (1983, marzo 4). Plenitud de la Familia. Palabras del Presidente Betancur en el acto celebrado con ocasión de la iniciación del año interamericano de la familia. Bogotá: Presidencia de la República.

BONILLA, E. (1982). La madre trabajadora: una contradicción. Desarrollo y Sociedad, 9, p. 69-84.

Decree 677 of 1972.

Decree 678 de 1972.

DEPARTAMENTO ADMINISTRATIVO NACIONAL DE ESTADÍSTICA \& DIRECCIÓN NACIONAL DE PLANEACIÓN. (1981). Encuesta Nacional de Alimentación, Nutrición y Vivienda. Bogotá: Departamento Administrativo Nacional de Estadística \& Dirección Nacional de Planeación.

DEPARTAMENTO NACIONAL DE PLANEACIÓN [DNP]. (1950). Economía colombiana último decenio. Recovered from: <https://colaboracion.dnp.gov.co/CDT/PND/Lleras3_Econo_Colombiana_Ultimo_ Decenio.pdf>. . (1970a). Plan Nacional de Desarrollo Las cuatro estrategias (1970-1974), Presentación. 
(1970b). Plan Nacional de Desarrollo Las cuatro estrategias (1970-1974), Componente Desarrollo Social. (1974a). Plan Nacional de Desarrollo Para cerrar la brecha (1974-1978), Presentación.

(1974c). Plan Nacional de Desarrollo "Para cerrar la brecha"(1974-1978), Programas Sociales.

(1978a). Plan Nacional de Desarrollo Plan de Integración (1978-1982). Aspectos generales.

(1978b). Plan Nacional de Desarrollo Plan de Integración (1978-1982). La nueva política social.

(1982a). Plan Nacional de Desarrollo Cambio con Equidad (1982-1986). Componente política social.

(1982b). Plan Nacional de Desarrollo Cambio con Equidad (1982-1986). Bases del Plan.

(1986a). Plan Nacional de Desarrollo Plan de Economía Social (1986-1990). Prólogo.

. (1986b). Plan Nacional de Desarrollo Plan de Economía Social (1986-1990). Plan de economía social.

Programas sectoriales para el desarrollo social.

EL TIEMPO, Archivo. Sección Política, (22 de agosto de 1997). "Gobierno de Misael Pastrana Borrero".

FRESNEDA et al. (2009). Reducción de la pobreza en Colombia: el impacto de las políticas públicas. PNUD.

Available at <http://www.fuac.edu.co/download/AREAS/10ipp.pdf > .

HALLEY, J. (2011a). “What is Family Law?: A Genealogy Part I”. Yale Law Journal, 23(1), p. 1-109.

(2011b). "What is Family Law?: A Genealogy Part I". Yale Law Journal, 23(2), p. 189-294.

; RITTICH, K. (2010). "Critical Directions in Comparative Family Law: Genealogies and

Contemporary Studies of Family Law Exceptionalism”. The American Journal of Comparative, 58, p. 753-775.

INSTITUTO COLOMBIANO DE BIENESTAR FAMILIAR [ICBF]. (1983). Memorias Año Interamericano de la Familia, Discurso Directora ICBF.

(nd.). ICBF History. Recovered from: <http://www.icbf.gov.co/portal/page/portal/IntranetICBF/ Sobre_intranet/acercade_ICBF>.

GONCALVES, C.J.; SOTO, A. (1992). Relaciones económicas entre Colombia y Estados Unidos: la búsqueda de mayor autonomía (1982-1992). Colombia Internacional, jul.-sept. 1992, p. 11-22.

KENNEDY, D. (2006). The "Rule of Law", Political Choices, and Development Common Sense. In: TRUBEK, D.; SANTOS, A. The New Law and Economic Development. Cambridge: Cambridge University Press. (2013). Law and Development Economics: Towards a New Alliance. In: STIGLITZ, J. E.;

KENNEDY, D. Law and Economics with Chinese Characteristics: Institutions for Promoting Development in the $21^{\text {st }}$ Century. Oxford: Oxford University Press.

. (1993). The Stakes of Law, or Hale and Foucault! In: KENNEDY, D. Sexy Dressing. Cambridge:

Harvard University Press.

(2006). Three Globalizations of Law and Legal Thought: 1850-2000. In: TRUBEK, D.; SANTOS, A.

The New Law and Economic Development. Cambridge: Cambridge University Press.

LÓPEZ MICHELSEN, A. (May 19, 1978). "El nuevo modelo de desarrollo". Texto del discurso pronunciado por el Presidente de la República al instalar la IV asamblea de instituciones financieras (ANIF).

MINISTRY OF LABOR AND SOCIAL SECURITY [MinTrabajo]. (1971). "Strategy for employment policy”. Bogotá. OCAMPO, J. A.; BERNAL, J.; AVELLA, M.; ERRÁZURIZ, M. (1994). La consolidación del capitalismo moderno (1945-1986). In: COLMENARES, G.; OCAMPO GAVIRIA, J. A. Historia económica de Colombia. Bogotá: Tercer mundo editores en coedición con fedesarrollo.

PARRA, R. (1987). La política social en Colombia 1975-1896. CEPAL. Reunión sobre Políticas Sociales, Transformación y Desarrollo en América Latina, Montevideo, Uruguay, 30 de junio al 3 de julio de 1987. PASTRANA, M. (1973). Mensaje del señor presidente de la República de Colombia doctor Misael Pastrana Borrero al Congreso Nacional: 20 de julio de 1973. Bogotá: Tall. Gráf. del Banco de la República.

PRESIDENCIA DE LA REPÚBLICA (1975). López Cumple. Protección para la mujer, el niño y la familia colombiana, Bogotá.

PRESIDENCIA DE LA REPÚBLICA, Consejería para la Reconciliación, la Normalización y la Rehabilitación [CRNR] \& Secretaría de Integración Nacional [SIN]. (1986). Plan Nacional de Rehabilitación. Una estrategia de desarrollo social y regional para la reconciliación. Bogotá: Presidencia de la República, Consejería para la Reconciliación, la Normalización y la Rehabilitación \& Secretaría de Integración Nacional.

REVISTA SEMANA (1983 Marzo 29). Construcción y vivienda. Available at: <http://www.semana.com/ especiales/articulo/construccion-vivienda/3423-3>.

REVISTA SEMANA (1986 Octubre 1). Lo bueno, lo malo y lo feo. Available at: <http://www.semana.com/ nacion/articulo/lo-bueno-lo-malo-lo-feo/8015-3>.

RITTICH, K. (2002). Recharacterizing Restructuring. Law, Distribution and Gender in Market Reform. The Hague: Kluwer Law International.

SECRETARÍA DE INTEGRACIÓN POPULAR [SIP]. (1975). "Programa General para el Desarrollo de la comunidad".

TURBAY, J.C. (1982). Hechos y cifras. Bogotá: Presidencia de la República. 
390 : ENGULFED BY THE FAMILY: WOMEN IN THE COLOMBIAN DEVELOPMENT STATE BETWEEN 1966 AND 1990

UNICEF, Ministerio de Salud Pública [MinSalud], Departamento Nacional de Planeación [DNP], (1970). Conferencia Nacional sobre Familia, Infancia y Juventud.

\section{Helena Alviar Garcia}

Bogotá - Colombia

Full Professor and DeAn of Universidad de Los Andes. I halviarßuniandes.edu.co 